RHODORA, Vol. 109, No. 940, pp. 430-447, 2007

(c) Copyright 2007 by the New England Botanical Club

\title{
LICHENS OF PINE HILL, A PERIDOTITE OUTCROP IN EASTERN NORTH AMERICA
}

\author{
Tanner B. Harris, Fred C. Olday, and Nishanta Rajakaruna ${ }^{1}$ \\ College of the Atlantic, 105 Eden Street, Bar Harbor, ME 04609 \\ ${ }^{1}$ Author for Correspondence; e-mail: nrajakaruna@coa.edu
}

\begin{abstract}
Despite a large body of work on the serpentine-substrate effect on vascular plants, little work has been undertaken to describe lichen communities growing on serpentine soils derived from peridotite and other ultramafic rocks. Most such work has been conducted in Europe and western North America. Only one study to date has examined the lichen flora of an ultramafic outcrop in eastern North America. The current paper examines the lichen flora of a peridotite outcrop from Deer Isle, Hancock County, Maine, U.S.A. The lichen flora is presented along with relevant ecological and geochemical data. Sixty-three species were found, comprising 35 genera. Two species, Buellia ocellata and Cladonia symphycarpia, are new reports for New England. Fuscopannaria praetermissa, Psorula rufonigra, and Spilonema revertens are new reports for Maine. Twenty species including one genus, Lobaria, are new reports for ultramafic soils worldwide. Buellia ocellata, P. rufonigra, and $S$. revertens are reported from several localities on the outcrop. Soil analyses were conducted for $\mathrm{pH}$, electrical conductivity, cation exchange capacity, heavy metals, and cations. Soil $\mathrm{pH}$ and cation and heavy metal concentrations are similar to those reported from west coast ultramafic soils suggesting that a similarly strong substrate effect may exist for species present on ultramafic soils in eastern North America.
\end{abstract}

Key Words: edaphic factor, lichen ecology, Maine lichens, serpentine ecology, ultramafic ecology

Peridotite belongs to the ultramafic family of rocks containing at least $70 \%$ ferromagnesian silicate minerals (Kruckeberg 2002). Soils weathered from peridotite and related rocks strongly reflect the mineral composition of the parent rock, frequently consisting of minerals such as antigorite, chrysotile, and lizardite commonly known as the serpentine group of minerals (Kruckeberg 1984). Soils enriched with such minerals, hereafter referred to as serpentine soils, are generally deficient in plant nutrients such as nitrogen, potassium, and phosphorus; have elevated levels of heavy metals such as iron, nickel, chromium, and cobalt; and have calcium to magnesium ratios $<1$ in addition to low calcium levels in comparison to surrounding soils (Brady et al. 2005). Combined with the generally rocky and exposed nature of ultramafic outcrops, 
these factors create a physiologically demanding environment inhospitable to many plants (Kruckeberg 1979). Because of the extreme selective pressure created by such chemical and physical conditions, serpentine soils have been cited as stimuli for speciation events (Kruckeberg 1986; Rajakaruna and Whitton 2004). They are known to harbor unique floras with high rates of endemism, and species with disjunct distributions (Brooks 1987; Whittaker 1954).

Despite extensive study over the last several decades, there has been no general agreement on the factors responsible for the unique plant assemblages found on serpentine soils. Most recent studies highlight low calcium to magnesium ratios and low calcium levels in comparison to surrounding soils (Brady et al. 2005). However, the heterogeneity of serpentine soils worldwide suggests that there is no single "serpentine factor," that the characteristic vegetative communities of each region are the result of each area's unique environmental, geochemical, and physical properties (Proctor and Nagy 1991). On a global scale, serpentine soils vary greatly, and attention must be paid to each site's particular geology as there may be considerable variation even within a single site (Coleman and Jove 1991; Rajakaruna and Bohm 1999). Despite such variance in soil chemistry, vegetation composition, and physiognomy, Whittaker (1954) and Kruckeberg (1969) identified three traits common to serpentine soils worldwide: (a) reduced plant productivity, (b) high rates of endemism, and (c) vegetation distinct from that of surrounding areas.

Much work has gone into elucidating the serpentine soil effect in western North America, Europe, Cuba, New Caledonia, and parts of Africa and southeastern Asia (Alexander et al. 2007; Brooks 1987; Kruckeberg 2002; Roberts and Proctor 1992). However, relatively scant information exists on the serpentine ecology of eastern North America. Only a small number of studies, mostly of vascular floras, have been undertaken for plants on east coast serpentine soils despite their patchy occurrence along the Appalachian mountain belt from the Gaspé Peninsula and Newfoundland through New England to Georgia (Brooks 1987; Dann 1988; Reed 1986). Serpentine outcrops from the Gaspé, Newfoundland, and New England are unique in their recent glaciation between 13,000 and 18,000 years ago (Hooke 2003). In theory, these sites are prime areas for modern speciation events similar to those that have shaped the unique floras of serpentine soils around the world (Rajakaruna 2004).

Worldwide, there have been relatively few studies of lichens on serpentine soils (Favero-Longo et al. 2004), and only one study to 
date has examined lichens on serpentine soils in eastern North America (Sirois et al. 1988). The intimate and often inseparable relationship between lichens and their substrates suggests a strong possibility of substrate effects for lichen species associated with extreme geoedaphic habitats (Brodo 1974). While it is clear that mineralogy plays an important role in lichen community assemblage (Purvis and Halls 1996), the exact mechanisms of this influence have proven elusive. A number of authors have documented metal uptake or accumulation in lichens (Burton et al. 1981; Goyal and Seaward 1981; Prussia and Killingbeck 1991; Pyatt et al. 1992). However, the complex interactions between lichens and rocks and lichens and metals have been cited by several authors (Purvis 1996; Richardson 1995; Wilson 1995), thereby increasing focus on investigations of the differences between trapped particulate matter, extracellular binding, and intracellular uptake.

In a comprehensive review of the lichen-serpentine literature from the beginning of the 20th century, Favero-Longo et al. (2004) found no consistent trends in lichen community assemblage or physiognomy on serpentine soils despite a seemingly general acceptance in the literature of common features such as low species richness and diversity, the cooccurrence of calcicolous and silicicolous species, and the presence of distinct lichen ecotypes. Despite the lack of consistent trends, it is clear from these reports that lichen communities on serpentine soils are distinct from their neighboring non-serpentine counterparts.

The current study examines the lichen flora of an abandoned peridotite quarry, Pine Hill, on Little Deer Isle, Hancock County, Maine, U.S.A. (Figure 1). The lichen flora is presented with relevant ecological and geochemical data from the site and compared with previous lichen floras of nearby Acadia National Park on Mt. Desert Island, Hancock County, Maine - an island subject to similar ecological conditions but lacking serpentine soils (Sullivan 1996; Wetmore 1984). Suggestions are made for further study to elucidate lichen-serpentine substrate relationships in eastern North America.

\section{SITE DESCRIPTION}

Pine Hill is a former peridotite quarry on Little Deer Isle, Hancock County, Maine, U.S.A. $\left(44^{\circ} 17^{\prime} 07.3^{\prime \prime} \mathrm{N}, 68^{\circ} 42^{\prime} 06.7^{\prime \prime} \mathrm{W}\right.$; 


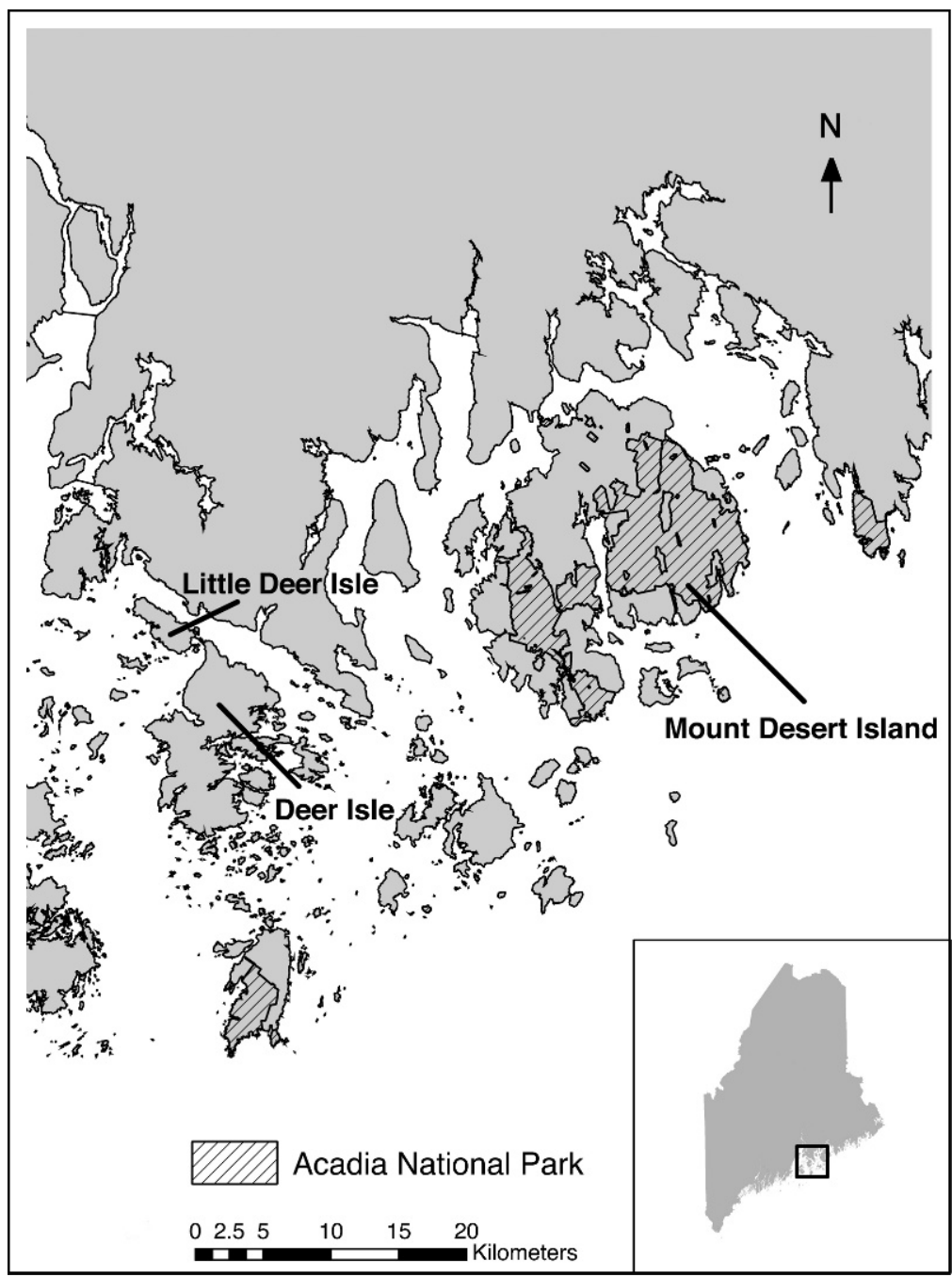

Figure 1. Locations of Little Deer Isle, Deer Isle, Mount Desert Island, and Acadia National Park in the Gulf of Maine (Credit: Marianna Bradley).

WGS 84). Due to its unique geology and associated biota, the site was declared a biological preserve in 2006 by the Island Heritage Trust of Deer Isle. The site is approximately $0.16 \mathrm{~km}^{2}$, located approximately $0.8 \mathrm{~km}$ inland from Penobscot Bay (Figure 1). Areas and distances are approximated from Stewart (1998). The outcrop 
is serpentinized peridotite formed during the Jurassic period (Hooke 2003). The area receives an average annual precipitation of $138.30 \mathrm{~cm}$ and an average annual snowfall of $181.86 \mathrm{~cm}$. The average annual temperature is $7.5^{\circ} \mathrm{C}$ ranging from an average $-4.5^{\circ} \mathrm{C}$ in February to $20.1^{\circ} \mathrm{C}$ in July. Averages were generated from data collected from 1985-2005 from National Oceanic and Atmospheric Administration weather station 170100/99999 located in Acadia National Park, Hancock County, Maine.

Quarry activities from approximately 1930-1960 have reduced the outcrop to a half dome and have exposed extensive vertical faces of unweathered rock with a southern exposure. The quarry floor is largely serpentinized gravel overlying bedrock with a number of large boulders near the base of the outcrop. The floor has been colonized by grasses, forbs, and small shrubs, primarily Juniperus communis var. depressa (Cupressaceae) and Morella pensylvanica (Myricaceae), but remains largely barren. The unquarried north, east, and west sides of the outcrop are vegetated by stunted conifers-Picea glauca (Pinaceae), Pinus strobus (Pinaceae), and Thuja occidentalis (Cupressaceae) - thinning near the top of the outcrop to a primarily grass-shrub vegetation. The base of the outcrop is surrounded by dense spruce-pine forest with little understory vegetation. A number of large peridotite boulders were deposited in the forest at the base of the outcrop and along the access road by quarry activities, creating serpentine soils in deep shade. Soils on the site range from coarse gravel at the quarry floor, to humus-rich organic debris along the three sides of the outcrop, and sandy loam at the top of the outcrop. A number of ephemeral freshwater seeps exist at the site, creating moist environments in an otherwise dry landscape.

MATERIALS AND METHODS

Lichens were collected on several dates from September to November, 2005, from rock and soil throughout Pine Hill, including peridotite debris deposited by quarry activity along the access road and in the forest surrounding the site. Lichens were collected from as many microhabitats as possible. Lichens occurring on non-peridotite rocks were not collected. A number of keys were used to identify specimens including: Arup 1994; Brodo 1988; Brodo et al. 2001; Fryday and Coppins 1997; Gowan and Brodo 1988; Harris 1977; Hinds and Hinds 1998b; Purvis et al. 
1992; and Thomson 1984, 1997. Taxa were verified from specimens in the herbaria of College of the Atlantic (HCOA), University of Maine at Orono (MAINE), The New York Botanical Garden (NY), and The New Brunswick Museum (NBM). Voucher specimens were deposited at HCOA, NBM, and NY. Nomenclature follows Esslinger (2006) except where indicated.

A total of 18 soil samples were taken in a semi-random pattern by choosing a location and taking three samples from three directions approximately three meters from the center point. Samples were taken in this fashion from two locations on the quarry floor and one location from each of the north, east, and west slopes, and the top of the outcrop. Samples were collected with a plastic hand trowel, air dried, and stored in plastic bags. Analyses were carried out on the $2 \mathrm{~mm}$ fraction obtained using a brass sieve. Electrical conductivity (EC) and $\mathrm{pH}$ values were measured following Kalra and Maynard (1991) using the 1:5 soil-to-water extraction method for EC and the 1:4 soil-to-solution method with $\mathrm{H}_{2} \mathrm{O}$ and $0.01 \mathrm{M}$ $\mathrm{CaCl}_{2}$ for $\mathrm{pH}$.

Metal, cation, and cation exchange capacity (CEC) analyses were conducted by the Analytical Laboratory at the Orono campus of the University of Maine. Soils were analyzed for $\mathrm{Cr}, \mathrm{Fe}, \mathrm{Ni}, \mathrm{Mn}$, $\mathrm{Cu}$, and $\mathrm{Zn}$ by extraction with $0.005 \mathrm{M}$ diethylene triamine pentaacetic acid (DTPA) buffered with triethanolamine to $\mathrm{pH} 7.3$ (Lindsay and Norvell 1978) and subsequent detection by inductively coupled plasma optical emission spectrometry (ICPOES) using matrix-matched calibration standards. Soils were analyzed for $\mathrm{Ca}, \mathrm{K}, \mathrm{Mg}, \mathrm{Na}$, and $\mathrm{CEC}$ by extraction with neutral ammonium acetate and concentrations determined by ICP-OES analysis.

\section{RESULTS}

Sixty-three species comprising 35 genera were identified from collections at the site (Table 1). Twenty-two species, including four genera, reported here were not listed among the 120 genera and 379 species found in Acadia National Park by Sullivan (1996) and Wetmore (1984). Two species reported here are previously unreported for New England: Buellia ocellata and Cladonia symphycarpia (Greene 2005a, 2005b). Three species are new reports for Maine: Fuscopannaria praetermissa, Psorula rufonigra, and Spilonema revertens (Hinds 1999; Hinds and Hinds 1998a; Lendemer and 
Table 1. Lichens of Pine Hill, Deer Isle, Maine. For each species, the type of substrate on which it was found at Pine Hill $(\mathrm{PH})$ is given as well as preferred substrate type (Sub; $\mathrm{C}=$ calcareous or basic substrates; $\mathrm{S}=$ siliceous or acidic substrates; $-=$ no preference indicated or no available information; Brodo et al. 2001; Purvis et al. 1992; Thomson 1984, 1997). Occurrence is indicated (x) in Acadia National Park (Acadia; Sullivan 1996; Wetmore 1984), Maine (Hinds 1999; Hinds and Hinds 1998a; Lendemer and Harris 2007), New England (NE; Greene 2005a, 2005b), and on serpentine sites worldwide (Serp; Favero-Longo et al. 2004). Nomenclature follows Esslinger (2006) except where noted.

\begin{tabular}{|c|c|c|c|c|c|c|}
\hline \multirow[b]{2}{*}{ Species } & \multicolumn{2}{|c|}{ Substrate } & \multicolumn{4}{|c|}{$\begin{array}{c}\text { Place of Species } \\
\text { Occurrence }\end{array}$} \\
\hline & $\mathrm{PH}$ & Sub & Acadia & Maine & $\mathrm{NE}$ & Serp \\
\hline Acarospora fuscata (Schrad.) Arnold & Rock & $\mathrm{S}$ & $\mathrm{x}$ & $\mathrm{x}$ & $\mathrm{x}$ & $\mathrm{x}$ \\
\hline Anaptychia palmulata (Michx.) Vain. & Rock & - & $\mathrm{x}$ & $\mathrm{x}$ & $\mathrm{x}$ & - \\
\hline Aspicilia cinerea (L.) Körb. & Rock & $\mathrm{S}$ & $\mathrm{x}$ & $\mathrm{x}$ & $\mathrm{x}$ & $\mathrm{x}$ \\
\hline Buellia ocellata (Flot.) Körb. & Rock & $\mathrm{S}$ & - & - & - & $\mathrm{x}$ \\
\hline Caloplaca lithophila $\mathrm{H}$. Magn. & Rock & - & - & $\mathrm{x}$ & $\mathrm{x}$ & - \\
\hline C. microthallina (Wedd.) Zahlbr. & Rock & - & $\mathrm{x}$ & $\mathrm{x}$ & $\mathrm{x}$ & - \\
\hline C. scopularis (Nyl.) Lettau & Rock & - & $\mathrm{x}$ & $\mathrm{x}$ & $\mathrm{x}$ & - \\
\hline \multicolumn{7}{|l|}{ Candelariella aurella (Hoffm.) } \\
\hline Zahlbr. & Rock & $\mathrm{C}$ & $\mathrm{x}$ & $\mathrm{x}$ & $\mathrm{x}$ & $\mathrm{x}$ \\
\hline C. vitellina (Hoffm.) Müll. Arg. & Rock & $\mathrm{S}$ & $\mathrm{x}$ & $\mathrm{x}$ & $\mathrm{x}$ & $\mathrm{x}$ \\
\hline Catillaria lenticularis (Ach.) Th. Fr. & Rock & $\mathrm{C}$ & - & $\mathrm{x}$ & $\mathrm{x}$ & $\mathrm{x}$ \\
\hline Cladonia acuminata (Ach.) Norrl. & Soil & - & - & $\mathrm{x}$ & $\mathrm{x}$ & $\mathrm{x}$ \\
\hline C. boryi Tuck. & Soil & - & $\mathrm{x}$ & $\mathrm{x}$ & $\mathrm{x}$ & - \\
\hline C. cariosa (Ach.) Spreng. & Soil & - & - & $\mathrm{x}$ & $\mathrm{x}$ & - \\
\hline C. cristatella Tuck. & Soil & - & $\mathrm{x}$ & $\mathrm{x}$ & $\mathrm{x}$ & $\mathrm{x}$ \\
\hline C. macilenta Hoffm. & Soil & - & $\mathrm{x}$ & $\mathrm{x}$ & $\mathrm{x}$ & - \\
\hline C. mitis Sandst. & Soil & - & $\mathrm{x}$ & $\mathrm{x}$ & $\mathrm{x}$ & $\mathrm{x}$ \\
\hline C. pleurota (Flörke) Schaer. & Soil & - & $\mathrm{x}$ & $\mathrm{x}$ & $\mathrm{x}$ & $\mathrm{x}$ \\
\hline C. polycarpoides Nyl. & Soil & - & - & $\mathrm{x}$ & $\mathrm{x}$ & - \\
\hline C. pyxidata (L.) Hoffm. & Soil & $\mathrm{S}$ & $\mathrm{x}$ & $\mathrm{x}$ & $\mathrm{x}$ & $\mathrm{x}$ \\
\hline C. rangiferina (L.) F.H. Wigg. & Soil & - & $\mathrm{x}$ & $\mathrm{x}$ & $\mathrm{x}$ & $\mathrm{x}$ \\
\hline C. rei Schaer. & Soil & - & - & $\mathrm{x}$ & $\mathrm{x}$ & - \\
\hline C. squamosa Hoffm. & Soil & - & $\mathrm{x}$ & $\mathrm{x}$ & $\mathrm{x}$ & $\mathrm{x}$ \\
\hline C. symphycarpia (Flörke) Fr. & Soil & $\mathrm{C}$ & - & - & - & $\mathrm{x}$ \\
\hline C. turgida Hoffm. & Soil & - & $\mathrm{x}$ & $\mathrm{x}$ & $\mathrm{x}$ & $\mathrm{x}$ \\
\hline C. uncialis (L.) F.H. Wigg. & Soil & - & $\mathrm{x}$ & $\mathrm{x}$ & $\mathrm{x}$ & $\mathrm{x}$ \\
\hline Collema subflaccidum Degel. & Rock & - & $\mathrm{x}$ & $\mathrm{x}$ & $\mathrm{x}$ & - \\
\hline \multicolumn{7}{|l|}{ Dermatocarpon miniatum (L.) } \\
\hline W. Mann & Rock & $\mathrm{C}$ & - & $\mathrm{x}$ & $\mathrm{x}$ & $\mathrm{x}$ \\
\hline \multicolumn{7}{|l|}{ Dibaeis baeomyces (L. f.) Rambold \& } \\
\hline Hertel & Soil & - & $\mathrm{x}$ & $\mathrm{x}$ & $\mathrm{x}$ & $\mathrm{x}$ \\
\hline Flavoparmelia caperata (L.) Hale & Rock & - & $\mathrm{x}$ & $\mathrm{x}$ & $\mathrm{x}$ & $\mathrm{x}$ \\
\hline \multicolumn{7}{|l|}{ Fuscopannaria praetermissa (Nyl.) } \\
\hline P.M. Jørg. & Soil & - & - & - & $\mathrm{x}$ & $\mathrm{x}$ \\
\hline Lecanora argentea Oksner \& Volkova & Rock & - & - & $\mathrm{x}$ & $\mathrm{x}$ & - \\
\hline
\end{tabular}


Table 1. Continued.

\begin{tabular}{|c|c|c|c|c|c|c|}
\hline \multirow[b]{2}{*}{ Species } & \multicolumn{2}{|c|}{ Substrate } & \multicolumn{4}{|c|}{$\begin{array}{c}\text { Place of Species } \\
\text { Occurrence }\end{array}$} \\
\hline & PH & Sub & Acadia & Maine & $\mathrm{NE}$ & Serp \\
\hline L. dispersa (Pers.) Sommerf. & Rock & $\mathrm{C}$ & $\mathrm{x}$ & $\mathrm{x}$ & $\mathrm{x}$ & $\mathrm{x}$ \\
\hline $\begin{array}{l}\text { L. polytropa (Hoffm.) Rabenh. } \\
\text { Lecidella stigmatea (Ach.) Hertel \& }\end{array}$ & Rock & $\mathrm{S}$ & - & $\mathrm{x}$ & $\mathrm{x}$ & $\mathrm{x}$ \\
\hline $\begin{array}{l}\text { Leukert } \\
\text { Lepraria caesioalba (de Lesd.) J.R. }\end{array}$ & Rock & $\mathrm{C}$ & - & $\mathrm{x}$ & $\mathrm{x}$ & $\mathrm{x}$ \\
\hline Laundon & Rock & - & $\mathrm{x}$ & $\mathrm{x}$ & $\mathrm{x}$ & - \\
\hline $\begin{array}{l}\text { L. neglecta (Nyl.) Erichsen } \\
\text { L. normandinoides Lendemer \& R.C. }\end{array}$ & Rock & $\mathrm{S}$ & $\mathrm{x}$ & $\mathrm{x}$ & $\mathrm{x}$ & $\mathrm{x}$ \\
\hline $\begin{array}{l}\text { Harris } \\
\text { Leptogium cyanescens (Rabenh.) }\end{array}$ & Rock & $\mathrm{S}$ & - & $\mathrm{x}$ & $\mathrm{x}$ & - \\
\hline Körb. & Rock & - & $\mathrm{x}$ & $\mathrm{x}$ & $\mathrm{x}$ & $\mathrm{x}$ \\
\hline Lobaria pulmonaria (L.) Hoffm. & Rock & - & $\mathrm{x}$ & $\mathrm{x}$ & $\mathrm{x}$ & - \\
\hline Nephroma parile (Ach.) Ach. & Rock & - & $\mathrm{x}$ & $\mathrm{x}$ & $\mathrm{x}$ & $\mathrm{x}$ \\
\hline Pannaria rubiginosa (Ach.) Bory & Rock & - & $\mathrm{x}$ & $\mathrm{x}$ & $\mathrm{x}$ & $\mathrm{x}$ \\
\hline Parmelia saxatilis (L.) Ach. & Rock & $\mathrm{S}$ & $\mathrm{x}$ & $\mathrm{x}$ & $\mathrm{x}$ & $\mathrm{x}$ \\
\hline P. sulcata Taylor & Rock & - & $\mathrm{x}$ & $\mathrm{x}$ & $\mathrm{x}$ & $\mathrm{x}$ \\
\hline $\begin{array}{l}\text { Parmotrema crinitum (Ach.) } \\
\text { M. Choisy }\end{array}$ & Rock & - & $\mathrm{x}$ & $\mathrm{x}$ & $\mathrm{x}$ & - \\
\hline $\begin{array}{l}\text { Peltigera didactyla (With.) J.R. } \\
\text { Laundon }\end{array}$ & Soil & - & - & $\mathrm{x}$ & $\mathrm{x}$ & $\mathrm{x}$ \\
\hline P. rufescens (Weiss) Humb. & Soil & $\mathrm{C}$ & $\mathrm{x}$ & $\mathrm{x}$ & $\mathrm{x}$ & $\mathrm{x}$ \\
\hline Pertusaria amara (Ach.) Nyl. & Rock & - & $\mathrm{x}$ & $\mathrm{x}$ & $\mathrm{x}$ & $\mathrm{x}$ \\
\hline Phaeophyscia adiastola (Essl.) Essl. & Rock & $\mathrm{S}$ & - & $\mathrm{x}$ & $\mathrm{x}$ & - \\
\hline P. rubropulchra (Degel.) Essl. & Rock & - & $\mathrm{x}$ & $\mathrm{x}$ & $\mathrm{x}$ & - \\
\hline P. sciastra (Ach.) Moberg & Rock & - & - & $\mathrm{x}$ & $\mathrm{x}$ & $\mathrm{x}$ \\
\hline $\begin{array}{l}\text { Physcia caesia (Hoffm.) Fürnr. } \\
\text { Placynthiella icmalea (Ach.) }\end{array}$ & Rock & - & - & $\mathrm{x}$ & $\mathrm{x}$ & $\mathrm{x}$ \\
\hline Coppins \& P. James & Rock & $\mathrm{S}$ & $\mathrm{x}$ & $\mathrm{x}$ & $\mathrm{x}$ & - \\
\hline $\begin{array}{l}\text { Porpidia subsimplex (H. Magn.) } \\
\text { Fryday }\end{array}$ & Rock & - & $\mathrm{x}$ & $\mathrm{x}$ & $\mathrm{x}$ & - \\
\hline $\begin{array}{l}\text { Psorula rufonigra (Tuck.) Gotth. } \\
\text { Schneider }\end{array}$ & & & & & & X \\
\hline Rhizocarpon geminatum Körb. & Rock & $\mathrm{S}$ & - & $\mathrm{x}$ & $\mathrm{x}$ & $\mathrm{x}$ \\
\hline $\begin{array}{l}\text { R. obscuratum (Ach.) A. Massal. } \\
\text { Scoliciosporum umbrinum (Ach.) }\end{array}$ & Rock & $\mathrm{S}$ & $\mathrm{x}$ & $\mathrm{x}$ & $\mathrm{x}$ & $\mathrm{x}$ \\
\hline Arnold & Rock & $\mathrm{S}$ & $\mathrm{x}$ & $\mathrm{x}$ & $\mathrm{x}$ & $\mathrm{x}$ \\
\hline Spilonema revertens $\mathrm{Nyl}$. & Rock & $\mathrm{S}$ & - & - & $\mathrm{x}$ & $\mathrm{x}$ \\
\hline Stereocaulon glaucescens Tuck. & Rock & - & - & $\mathrm{x}$ & $\mathrm{x}$ & $\mathrm{x}$ \\
\hline Xanthoparmelia cumberlandia (Gyeln. & & & & & & \\
\hline Hale & Rock & - & $\mathrm{x}$ & $\mathrm{x}$ & $\mathrm{x}$ & $\mathrm{x}$ \\
\hline$X$. plittii (Gyeln.) Hale & Rock & - & $\mathrm{x}$ & $\mathrm{x}$ & $\mathrm{x}$ & - \\
\hline Xanthoria elegans (Link) Th. Fr. & Rock & - & $\mathrm{x}$ & $\mathrm{x}$ & $\mathrm{x}$ & $\mathrm{x}$ \\
\hline X. parietina (L.) Th. Fr. & Rock & - & $\mathrm{x}$ & $\mathrm{x}$ & $\mathrm{x}$ & $\mathrm{x}$ \\
\hline
\end{tabular}


Harris 2007). Psorula rufonigra and $S$. revertens were found together at several localities on the outcrop while C. symphycarpia and $F$. praetermissa were found only once. Spot tests $(\mathrm{Pd}+$ yellow, $\mathrm{K}+\mathrm{red}$ ) for the specimen of $C$. symphycarpia indicated that it is the atranorin and norstictic acid chemical race discussed in Brodo et al. (2001). Six macro species reported here are reported as uncommon to Maine by Hinds and Hinds (1998a): Cladonia acuminata, C. polycarpoides, Pannaria rubiginosa, Phaeophyscia sciastra, Stereocaulon glaucescens, and Xanthoparmelia plittii.

Twenty species reported here are previously unreported from ultramafic substrates: Anaptychia palmulata, Caloplaca lithophila, C. microthallina, C. scopularis, Cladonia boryi, C. cariosa, C. macilenta, C. polycarpoides, C. rei, Collema subflaccidum, Lecanora argentea, Lepraria caesioalba, L. normandinoides, Lobaria pulmonaria, Parmotrema crinitum, Phaeophyscia adiastola, P. rubropulchra, Placynthiella icmalea, Porpidia subsimplex, and Xanthoparmelia plittii (Table 1; Favero-Longo et al. 2004 and sources therein). The genus Lobaria (Schreber) Hoffm., found growing directly on rock, is reported here from serpentine for the first time. None of a number of serpentinophytic lichen species reported by various authors (cited in Favero-Longo et al. 2004) were found at the site. Of the 63 species listed in Table 1, approximately 60\% are macrolichens and $40 \%$ are microlichens, $70 \%$ were found on rock and $30 \%$ on soil, $11 \%$ are known to have affinity toward calcareous or basic substrates, and $25 \%$ are known to have affinity toward siliceous or acidic substrates (Table 2). Of the saxicolous species listed, $45 \%$ are macrolichens and 55\% are microlichens, $11 \%$ are known from calcareous or basic substrates and 34\% from siliceous or acidic substrates (Brodo et al. 2001; Purvis et al. 1992; Thomson 1984, 1997). Of the terricolous species, $95 \%$ are macrolichens and $5 \%$ are microlichens, $11 \%$ show affinity for calcareous or basic substrates and 5\% toward siliceous or acidic substrates. Several species are known from nutrient-enriched sites such as bird perches. None of the taxa found indicate significant range extensions for North America (Brodo et al. 2001; Nash et al. 2002; Thomson 1984, 1997).

Findings from the soil analyses are reported in Table 3 . At the site, $\mathrm{pH}$ ranged from 5.4-7.8 in $\mathrm{H}_{2} \mathrm{O}$ and 4.8-7.1 in $0.01 \mathrm{M} \mathrm{CaCl}_{2}$. Sixteen of 18 samples at Pine Hill showed Ca: Mg ratios $<1$. Ni concentrations at the site ranged from $12.09-101.19 \mu \mathrm{g} / \mathrm{g}$. 
Table 2. Ecological features of the Pine Hill lichen flora including percentage of saxicolous and terricolous species, macro and micro species, and calcicolous and silicicolous species for the total flora and by substrate type.

\begin{tabular}{lcccccc}
\hline & \multicolumn{3}{c}{ Lichen Flora } & & \multicolumn{2}{c}{ Known Affinity } \\
\cline { 2 - 3 } Substrate & Total & Macro & Micro & & Calcicolous Silicicolous \\
\hline Saxicolous & $70 \%$ & $45 \%$ & $55 \%$ & & $11 \%$ & $34 \%$ \\
Terricolous & $30 \%$ & $95 \%$ & $5 \%$ & & $11 \%$ & $5 \%$ \\
All & - & $60 \%$ & $40 \%$ & & $11 \%$ & $25 \%$ \\
\hline
\end{tabular}

DISCUSSION

Relative to the outcrop's size, the Pine Hill lichen flora is among the more species-rich lichen floras reported from serpentine substrates (Favero-Longo et al. 2004). This could be due to 1) the dilution effects of glacial till, 2) a heavy maritime influence, 3) the site's wide range of favorable microhabitats, such as ephemeral seeps and heavily shaded portions of the outcrop, or 4) the sheltered nature of the outcrop's location created by the dense forest surrounding the site. The high species richness could also be a result of under-collection at other sites.

The ecophysiological features of the Pine Hill lichen flora are similar to those of other serpentine lichen floras from North America. The cooccurrence of calcicolous species, silicicolous species, and species common to nutrient enriched sites has also been reported from serpentine sites in California (Sigal 1989), on Fidalgo Island, Washington (Ryan 1988), and at Mt. Albert on the Gaspé Peninsula, Canada (Sirois et al. 1988), as well as from serpentine sites around the world (Favero-Longo et al. 2004). Sirois et al. (1988) reported a similar ratio of saxicolous to terricolous species for Mt. Albert. The Pine Hill lichen flora shows seven species in common with Ryan (1988), ten with Sigal (1989), and nineteen with Sirois et al. (1988).

Sullivan (1996) and Wetmore (1984) reported 120 genera from Acadia National Park on Mt. Desert Island, an area several orders of magnitude larger than Pine Hill, yet with a similar diversity of habitats and ecological conditions, excluding serpentine outcrops. The 120 genera include epiphytic species in addition to terricolous and saxicolous species, suggesting that the 35 genera we found solely from serpentine rock and soil at Pine Hill is high for the region. However, little statistical data exists for local lichen 


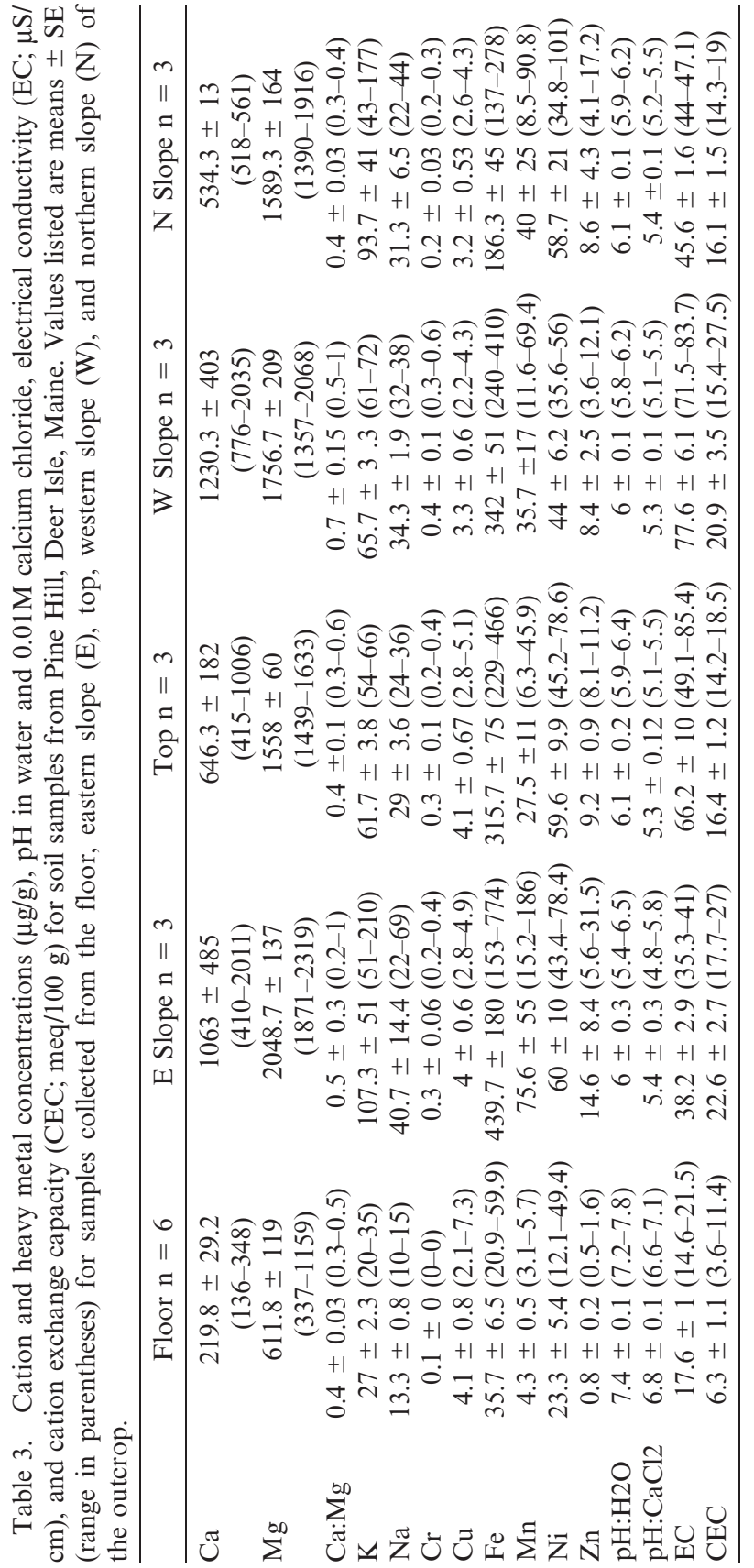


communities, making it difficult to compare the site's species richness to that of similarly exposed sites off serpentine.

The species reported as new to New England (Buellia ocellata and Cladonia symphycarpia) and Maine (Fuscopannaria praetermissa, Psorula rufonigra, and Spilonema revertens) merit some discussion, since they occur in a range of habitats elsewhere. Although no reference to B. ocellata is given in Brodo et al. (2001) or Thomson (1997), Purvis et al. (1992) listed it as common on acidic substrates in both Europe and North America. Thomson (1984) listed C. symphycarpia as a circumpolar species on basic soils in arctic to temperate regions. Brodo et al. (2001) listed it as common in open habitats on thin, sandy soils while Purvis et al. (1992) listed it as rare, occurring on coastal limestone in Great Britain and other localities throughout Europe and North America. Fuscopannaria praetermissa was listed as a common artic-alpine species in North America by Brodo et al. (2001) while Purvis et al. (1992) listed it as rare, occurring in isolated areas of Great Britain and Europe above approximately $750 \mathrm{~m}$. Although no published reports of $P$. rufonigra indicate its presence in Maine, the range map presented by Brodo et al. (2001) indicates its presence throughout New England. Thomson (1997) similarly listed it as a circumpolartemperate species ranging south to Massachusetts in the east. Because $P$. rufonigra exists as a parasite on $S$. revertens, Brodo et al. (2001) suggested that the latter species is likely to be more widespread in North America than has been documented, and that a closer inspection of $P$. rufonigra specimens would reveal a wider range for $S$. revertens. Purvis et al. (1992) did not indicate its presence in Great Britain. Such conflicting reports indicate that the new reports given here could be the result of under-collection of lichens in general as well as under-collection on serpentine soils. However, this could also indicate a unique ecological component at the Pine Hill site, such as release from competition by species with lower metal tolerance and an adaptation to the unique combination of geochemical and physical soil properties that exist at the site.

Soil analyses indicate that the site has geochemical and physical properties similar to serpentine soils reported from the west coast. Kruckeberg (1992) reported $\mathrm{pH}$ values from the west coast between 6.2-8.8, while Rajakaruna and Bohm (1999) reported values between 6.2-7.1. Sixteen of 18 samples at Pine Hill showed Ca:Mg ratios $<1$ as reported by Kruckeberg (1992) and other authors 
(Alexander et al. 2007). Nickel concentrations at the site ranged from 12.09-101.19 $\mu \mathrm{g} / \mathrm{g}$. Rajakaruna and Bohm (1999) report Ni concentrations from the west coast between $34.7-190.8 \mu \mathrm{g} / \mathrm{g}$. While the geochemical properties are similar to reports from west coast serpentine, the Pine Hill site shows a greater variability than most west coast sites, likely due to the non-residual nature of its soils. A more comprehensive soil survey might elucidate clearer soilvegetation trends and within-site geochemical variation such as the increase in $\mathrm{Ca}, \mathrm{Mg}$, and $\mathrm{Fe}$, and decrease in $\mathrm{pH}$ from the quarry floor to the outcrop's slopes and summit suggested by the data.

Thrall et al. (College of the Atlantic, unpubl. data) examined the vascular flora of Pine Hill and other serpentinized areas on Deer Isle, noting the presence of a rare serpentine indicator fern, Asplenium trichomanes (Aspleniaceae), a serpentine endemic fern, Adiantum aleuticum (Pteridaceae), the high abundance of a regionally rare species, Selaginella rupestris (Selaginellaceae), and several bodenvag species-Achillea millefolium (Asteraceae), Fragaria virginiana (Rosaceae), Oenothera biennis (Onagraceae) - with early flowering times. These preliminary observations suggest a serpentine effect for vascular flora at Pine Hill similar to that of serpentine sites in western North America. The discovery of the serpentine endemic fern A. aleuticum (Paris and Windham 1988) on moist, shaded serpentine substrates in other Deer Isle locations suggests a serpentine effect for other parts of the island as well.

The presence of a number of saxicolous and terricolous lichen species not reported as locally present (Sullivan 1996; Wetmore 1984), as well as two species new to New England (Greene 2005a, 2005b) and three to Maine (Hinds 1999; Hinds and Hinds 1998a; Lendemer and Harris 2007), suggests the possibility of a serpentine effect for lichens as well. However, because of the area's recent glaciation (13,000-18,000 years ago) and the dilution effect of glacial till (Hooke 2003), such a serpentine-substrate effect is not likely to be as distinct as that found in longer-exposed serpentine outcrops in similar climates.

To elucidate further the lichen-substrate relationship in Maine, a careful comparative study of local herbarium collections and voucher specimens should be made to evaluate possible trends in morphology that could indicate serpentinomorphosis (FaveroLongo et al. 2004) or possible taxonomic divergence. Lichen diversity statistics should be collected for the Pine Hill and other serpentine sites on Deer Isle (Hooke 2003) and the rest of Maine 
(Caldwell 1998). These could be compared with those presented in the literature and from adjacent non-serpentine sites to determine possible differences in local lichen community structure on and off serpentine. A systematic soil analysis should be done for each site and its surrounding area to get a better picture of substrate diversity trends in relation to lichen abundance and local non-serpentine soils. Benner and Vitousek (Stanford Univ., unpubl. data) have recently shown that epiphytic lichens show clear responses to soilnutrient additions, suggesting that such communities could show unique responses to naturally occurring nutrient imbalances and might well be considered in the context of serpentine lichen floras.

In addition to a more detailed taxonomic study and communitylevel analysis of lichen species on and off serpentine, a systematic tissue analysis for elements such as $\mathrm{Ni}, \mathrm{Cr}, \mathrm{Fe}, \mathrm{Ca}$, and $\mathrm{Mg}$ should be conducted for genera at the site with known metallophytes, metal accumulators, or metal indicators. This is especially important for those genera reported from other extreme geoedaphic habitats such as mine tailings (Dongarra et al. 1995; Garty 1993; Purvis and Halls 1996). Examples include: Acarospora (Purvis 1996; Purvis and Halls 1996), Aspicilia (Purvis 1996), Buellia (Purvis 1996), Cladonia (Burton et al. 1981; Chettri et al. 1997; Purvis 1996), Lecanora (Czehura 1977; Purvis 1996), Lecidea (Purvis 1996; Purvis and Halls 1996; Purvis and James 1985), Lecidella (Purvis and Halls 1996), Micarea (Purvis and Halls 1996), Peltigera (Purvis 1996), Porpidia (Purvis and Halls 1996), Rhizocarpon (Purvis 1996; Purvis and Halls 1996), Scoliciosporum (Purvis and Halls 1996), Lepraria (Purvis and Halls 1996), Stereocaulon (Purvis 1996; Pyatt et al. 1992), Xanthoparmelia (Chettri et al. 1997), and Xanthoria (Dongarra et al. 1995). The presence of metal accumulators or known indicators at the site would be valuable for understanding local lichen communities on metal-enriched soil and may be useful for geoprospecting or local pollution monitoring as well as understanding evolutionary patterns of metal-tolerance and substrate specificity in lichens.

ACKNOWLEDGMENTS. The authors thank Dick Harris (New York Botanical Garden) and Stephen Clayden (New Brunswick Museum) for their generous help with identifications, Chiquita Culberson (Duke University) for assistance with Thin Layer Chromatography, and Clifford Wetmore (University of Minnesota) for his Acadia National Park data set. The authors also thank Bruce A. 
Bohm (University of British Columbia) and two anonymous reviewers for useful comments on the manuscript, and Ann and Roger Hooke (Island Heritage Trust, Deer Isle) for their continuing support of our research efforts at Pine Hill. This project was partially funded by grants for undergraduate student research from the Maine Space Grant Consortium $(2005,2006)$.

\section{LITERATURE CITED}

Alexander, E. B., R. G. Coleman, T. Keeler-Wolf, and S. P. Harrison. 2007. Serpentine Geoecology of Western North America. Geology, Soils, and Vegetation. Oxford Univ. Press, New York.

Arup, U. 1994. The genus Caloplaca on seashore rocks of eastern North America. Bryologist 97: 377-392.

Brady, K. U., A. R. Kruckeberg, and H. D. Bradshaw Jr. 2005. Evolutionary ecology of plant adaptation to serpentine soils. Annual Rev. Ecol. Evol. Syst. 36: 243-266.

Brodo, I. M. 1974. Substrate ecology, pp. 401-441. In: V. Ahmadjian and M. E. Hale, eds., The Lichens. Academic Press, New York.

. 1988. Lichens of the Ottawa Region. Ottawa Field-Naturalists' Club, Ottawa, ON, Canada.

, S. D. Scharnoff, and S. Scharnoff. 2001. The Lichens of North America. Yale Univ. Press, London, U.K.

Brooks, R. R. 1987. Serpentine and its Vegetation: A Multidisciplinary Approach. Dioscorides Press, Portland, OR.

Burton, M. A. S., P. Le Sueur, and K. J. Puckett. 1981. Copper, nickel, and thallium uptake by the lichen Cladonia rangiferina. Canad. J. Bot. 59: 91-98.

Caldwell, D. W. 1998. Roadside Geology of Maine. Mountain Press Publishing Company, Missoula, MT.

Chettri, M. K., T. Sawidis, and S. Karataglis. 1997. Lichens as a tool for biogeochemical prospecting. Ecotoxicol. Environm. Safety 38: 322-335.

Coleman, R. G. and C. Jove. 1991. Geological origin of serpentinites, pp. 469-494. In: A. J. M. Baker, J. Proctor, and R. D. Reeves, eds., The Vegetation of Ultramafic (Serpentine) Soils: Proceedings of the First International Conference on Serpentine Ecology. Intercept Ltd., Andover, Hampshire, U.K.

Czenura, S. J. 1977. A lichen indicator of copper mineralization, Lights Creek District, Plumas County, California. Econ. Geol. 72: 796-803.

DAnN, K. T. 1988. Traces on the Appalachians: A Natural History of Serpentine in Eastern North America. Rutgers Univ. Press, New Brunswick, NJ.

Dongarra, G., D. Ottonello, G. Sabatino, and M. Triscari. 1995. Use of lichens in detecting environmental risk and in geochemical prospecting. Environm. Geol. 26: 139-146.

Esslinger, T. L. 2006. A cumulative checklist for the lichen-forming, lichenicolous, and allied fungi of the continental United States and 
Canada. North Dakota State Univ., Fargo, ND. Website (http:// www.ndsu.nodak.edu/instruct/esslinge/chcklst/chcklst7.htm). Most recently accessed $01 \mathrm{Feb} 2007$.

Favero-Longo, S. E., D. Isocrono, and R. Piervittori. 2004. Lichens and ultramafic rocks: A review. Lichenologist 36: 391-404.

Fryday, A. And B. Coppins. 1997. Keys to sterile, crustose saxicolous and terricolous lichens occurring in the British Isles. Lichenologist 29: 301-332.

GARTY, J. 1993. Lichens as biomonitors for heavy metal pollution, pp. 193-257. In: B. Markert, ed., Plants as Biomonitors: Indicators for Heavy Metals in the Terrestrial Environment. VCH, Cambridge, U.K.

Gowan, S. P. And I. M. Brodo. 1988. The Lichens of Fundy National Park, New Brunswick, Canada. Bryologist 91: 255-325.

Goyal, R. AND M. R. D. SeAward. 1981. Metal uptake in terricolous lichens. I. Metal localization within the thallus. New Phytol. 89: 631-635.

Greene, D. N. 2005a. Macrolichens of New England. Published electronically by the author. Website (http://www.hometown.aol.com/atmame77/page/ macrolichenne.htm). Most recently accessed 01 Feb 2007.

- 2005b. Microlichens of New England. Published electronically by the author. Website (http://www.hometown.aol.com/atmame77/page/ microlichenne.htm). Most recently accessed 01 Feb 2007.

Harris, R. C. 1977. Lichens of the Straits Counties, Michigan. Published by the author, Univ. Michigan Herbarium, Ann Arbor, MI.

Hinds, J. W. 1999. Crustose lichens of Maine. Compiled from the literature by the author, Orono, ME.

AND P. L. Hinds. 1998a. An annotated checklist of Maine macrolichens, pp. 345-376. In: M. G. Glenn, R. C. Harris, R. Dirig, and M. S. Cole, eds., Lichenographia Thomsoniana: North American Lichenology in Honor of John W. Thomson. Mycotaxon Ltd., Ithaca, NY.

Hinds, P. L. AND J. W. Hinds. 1998b. Simplified Key to Maine Macrolichens. Published by the authors, Orono, ME.

Hooke R. LeB. 2003. A Geologic History of Deer Isle, Maine: A Thumb Nail Sketch. Published by the author, Orono, ME.

Kalra, Y. P. and D. G. Maynard. 1991. Methods Manual for Forest Soil and Plant Analysis. Information Report NOR-X-319, Canadian Forest Service, Edmonton, AB, Canada.

Kruckeberg, A. R. 1969. Plant life on serpentinite and other ferromagnesian rocks in northwestern North America. Syesis 2: 15-114. . 1979. Plants that grow on serpentine: A hard life. Davidsonia 10: 21-29. . 1984. California Serpentines: Flora, Vegetation, Geology, Soils, and Management Problems. Univ. California Press, Berkeley, CA.

1986. An essay: The stimulus of unusual geologies for plant speciation. Syst. Bot. 11: 455-463.

. 1992. Plant life of western North American ultramafics, pp. 31-73. In:

B. A. Roberts and J. Proctor, eds., The Ecology of Areas with Serpentinized Rocks: A World View. Kluwer Academic Publishers, Dordrecht, The Netherlands.

2002. Geology and Plant Life: The Effects of Landforms and Rock

Type on Plants. Univ. Washington Press, Seattle, WA. 
Lendemer, J. C. And R. C. Harris. 2007. Lepraria normandinoides, a new widespread species from eastern North America. Opusc. Philolichenum 4: 45-50.

Lindsay, W. L. AND W. A. Norvell. 1978. Development of a DTPA soil test for zinc, iron, manganese, and copper. J. Soil Sci. 42: 421-428.

Nash, T. H., B. R. Ryan, C. Gries, and F. Bungartz. 2002. Lichen Flora of the Greater Sonoran Desert Region, Vol. 1. Lichens Unlimited, Arizona State Univ., Tempe, AZ.

Paris, C. A. AND M. D. Windham. 1988. A biosystematic investigation of the Adiantum pedatum complex in eastern North America. Syst. Bot. 13: 240-255.

Proctor, J. AND L. NAGy. 1991. Ultramafic rocks and their vegetation: An overview, pp. 469-494. In: A. J. M. Baker, J. Proctor, and R. D. Reeves, eds., The Vegetation of Ultramafic (Serpentine) Soils: Proceedings of the First International Conference on Serpentine Ecology. Intercept Ltd., Andover, Hampshire, U.K.

Prussia, C. M. And K. T. KillingbeCK. 1991. Concentrations of ten elements in two common foliose lichens: Leachability, seasonality, and the influence of rock and tree back substrates. Bryologist 94: 135-142.

Purvis, O. W. 1996. Interactions of lichens with metals. Sci. Progr. 79: 283-309.

- B. J. Coppins, D. L. Hawksworth, P. W. James, and D. M. Moore. 1992. The Lichen Flora of Great Britain and Ireland. Natural History Museum Publications, London, U.K.

AND C. Halls. 1996. A review of lichens in metal-enriched environments. Lichenologist 28: 571-601.

and P. W. James. 1985. Lichens of the Coniston Copper Mines. Lichenologist 17: 221-237.

Pyatt, F. B., E. H. Beaumont, D. Lacy, and D. M. Storey. 1992. Accumulation of lead by the lichen Stereocaulon dactylophyllum. Environmentalist 12: 207-210.

Rajakaruna, N. 2004. The edaphic factor in the origin of species. Int. Geol. Rev. 46: 471-478.

AND B. A. Bohm. 1999. The edaphic factor and patterns of variation in Lasthenia californica (Asteraceae). Amer. J. Bot. 86: 1576-1596.

- And J. Whitton. 2004. Trends in the evolution of edaphic specialists with an example of parallel evolution in the Lasthenia californica complex, pp. 103-110. In: Q. C. B. Cronk, J. Whitton, R. H. Ree, and I. E. P. Taylor, eds., Plant Adaptation: Molecular Genetics and Ecology. National Research Council Research Press, Ottawa, ON, Canada.

Reed, C. F. 1986. Flora of the Serpentine Formations in Eastern North America: With Descriptions of Geomorphology and Mineralogy of the Formations. Contrib. 30, Reed Herbarium, Baltimore, MD.

Richardson, D. H. S. 1995. Metal uptake in lichens. Symbiosis 18: 119-127.

Roberts, B. A. and J. Proctor, eds. 1992. The Ecology of Areas with Serpentinized Rocks: A World View. Kluwer Academic Publishers, Dordrecht, The Netherlands.

RYAN, B. D. 1988. Marine and maritime lichens on serpentine rock on Fidalgo Island, Washington. Bryologist 91: 186-190. 
Sigal, L. L. 1989. The lichens of serpentine rocks and soils in California. Mycotaxon 34: 221-238.

Sirois, L., F. Lutzoni, And M. M. Grandtner. 1988. Les lichens sur serpentine et amphibolite du plateau du mont Albert, Gaspésie, Québec. Canad. J. Bot. 66: 851-862.

Stewart, D. B. 1998. Geology of Northern Penobscot Bay, Maine. U.S. Geological Survey Miscellaneous Investigation Series Map I-2551. U.S.G.S. New England Mapping Partnership Office, Northborough, MA.

Sullivan, T. J. 1996. The Lichens of Acadia National Park, Maine. Ph.D. dissertation, Univ. Minnesota, Minneapolis, MN.

Thomson, J. W. 1984. American Arctic Lichens. 1. The Macrolichens. Columbia Univ. Press, New York.

- 1997. American Arctic Lichens. 2. The Microlichens. Univ. Wisconsin Press, Madison, WI.

Wetmore, C. M. 1984. Lichens and Air Quality in Acadia National Park. National Park Service Contract CX 0001-2-0034. National Park Service, Denver, CO.

Whittaker, R. H. 1954. The ecology of serpentine soils. IV. The vegetation response to serpentine soils. Ecology 35: 275-288.

WiLson, M. J. 1995. Interactions between lichens and rocks: A review. Cryptog. Bot. 5: 299-305. 